\title{
Bone parameters and organ morphometry of two broiler chicken lines exposed to heat for different periods
}

\section{Parâmetros ósseos e morfometria de órgãos de duas linhagens de frangos de corte mantidos sob diferentes tempos de exposição ao calor}

\author{
Cintia Amaral Moraes ${ }^{1 *}$; João Paulo Rodrigues Bueno ${ }^{1}$; Mara Regina Bueno de \\ Mattos Nascimento²; Fernanda Heloisa Litz ${ }^{1}$; Luciana Ruggeri Menezes Gotardo ${ }^{3}$; \\ Ednaldo Carvalho Guimarães ${ }^{2}$
}

\begin{abstract}
The objective of this study was to evaluate the effects of different times of exposure to heat on bone parameters and organ morphometry of Cobb Slow ${ }^{\circledR}$ and Hubbard Flex ${ }^{\circledR}$ broilers exposed to high temperatures for 1, 2 or $3 \mathrm{~h}$ daily, from 14 days of age. A total of 1120 one-day-old male chicks (half of each line; average weight of $44 \mathrm{~g}$ ) were housed into 32 cages with 35 birds each, in a randomizedblock experimental design. From the first to the 13th day of age, the birds remained under the thermal conditions recommended for their lines; thereafter, from the 14th day, the shed was separated into four parallel sections of $5.60 \times 10.20 \times 2.8 \mathrm{~m}$ delimited by double-sided plastic curtains along the width of the shed. Cyclic heat stress was generated by average temperatures of $36{ }^{\circ} \mathrm{C}$ from $14-20$ days, $35{ }^{\circ} \mathrm{C}$ from 21-27 days, $34{ }^{\circ} \mathrm{C}$ from $28-34$ days and $33{ }^{\circ} \mathrm{C}$ from $35-42$ days. The total length, width, density and mineral matter of the tibia; the size of the duodenum, jejunum and ileum; and the weights of the bursa of Fabricius and spleen were measured. No interaction effect between thermal environment and line was observed. Heat stress for up to $3 \mathrm{~h}$ daily, from the 14th to the 41st day of age, led to a longer but narrower tibia. There was no influence on small intestine morphometry. The Hubbard line presented longer and wider tibiae as well as higher relative and absolute weights of the bursa. In conclusion, heat stress from $2 \mathrm{~h}$ daily modifies the structure of the tibia in broilers, which increases in length and reduces in width, but heat exposure has no influence on the small intestine or lymphoid organs. The Hubbard line shows better tibia development than the Cobb line as well as different primary lymphoid responses, represented by a heavier bursa.
\end{abstract}

Key words: Bursa. Heat stress. Intestines. Poultry. Tibia.

\section{Resumo}

Objetivou-se avaliar os efeitos de diferentes tempos de exposição ao calor sobre os parâmetros ósseos e morfometria de órgãos de frango de corte Cobb Slow ${ }^{\circledR}$ e Hubbard Flex ${ }^{\circledR}$ expostos à temperatura elevada por $1 \mathrm{~h}, 2 \mathrm{~h}$ e $3 \mathrm{~h}$ diárias a partir de 14 dias de idade. Foram alojados 1120 pintos de cortes machos de um dia, distribuídos em delineamento de blocos casualizados, sendo metade de cada linhagem (peso

\footnotetext{
1 Discentes, Curso de Doutorado do Programa de Pós-Graduação em Ciências Veterinárias, Universidade Federal de Uberlândia, UFU, Uberlândia, MG, Brasil. E-mail: moraescintia@yahoo.com.br; jprbueno@hotmail.com; fernandalitz@veterinaria.med.br

2 Profs., Programa de Pós-Graduação em Ciências Veterinárias, UFU, Uberlândia, MG, Brasil. E-mail: maran@ufu.br; ecg@ufu.br

3 Discente, Curso de Doutorado do Programa de Pós-Graduação em Engenharia de Alimentos, Universidade de São Paulo, USP, Pirassununga, SP, Brasil. E-mail: luciana.ruggeri@hotmail.com

* Author for correspondence
} 
médio de $44 \mathrm{~g}$ ) em 32 boxes com 35 aves cada. Do primeiro ao $13^{\circ}$ dia de idade as aves permaneceram em condições térmicas de acordo com o recomendado para a linhagem, a partir do $14^{\circ}$ dia, o galpão foi separado em quatro seções paralelas de 5,60 x 10,20 x 2,8m delimitadas por cortinas plásticas dupla face ao longo da largura do galpão. $\mathrm{O}$ estresse cíclico por calor foi gerado com temperaturas médias de $14-20$ dias: $36^{\circ} \mathrm{C} ; 21-27$ dias: $35^{\circ} \mathrm{C} ; 28-34$ dias: $34^{\circ} \mathrm{C}$ e $35-42$ dias: $33^{\circ} \mathrm{C}$. O comprimento total, largura, densidade e matéria mineral do osso tíbia; tamanho do duodeno, jejuno e íleo e o peso da bursa e do baço foram determinados. Não foi observado interação entre ambiente térmico e linhagens. $\mathrm{O}$ estresse por calor no período de até 3 horas diárias, do $14^{\circ}$ ao $41^{\circ}$ dia de idade aumentou o comprimento e reduziu a largura do osso tíbia. Não houve influência na morfometria do intestino delgado. A linhagem Hubbard apresentou maiores comprimento e largura da tíbia, bem como maiores pesos relativo e absoluto da bursa. Concluiu-se que o estresse por calor a partir de 2 horas diárias modifica a estrutura da tíbia de frangos de corte, com aumento de seu comprimento e redução de sua largura, porém não há influência da exposição ao calor sobre o intestino delgado e órgãos linfoides. A linhagem Hubbard apresenta melhor desenvolvimento do osso tíbia em relação à Cobb, bem como respostas linfoides primárias diferentes, representada por maior peso da bursa.

Palavras-chave: Ave. Bursa. Estresse por calor. Intestinos. Tíbia.

\section{Introduction}

Brazilian poultry farmers are still concerned about the effects of high environmental temperatures on bird performance and welfare. In broiler chickens, high temperatures are known to compromise yield and immune parameters (ALAGAWANY et al., 2017).

Elevated temperatures in the rearing environment of broiler chickens are one of the main factors influencing production performance, since they negatively affect physiological characteristics (UZUM; ORAL TOPLU, 2013). Although studies have shown the diverse periods of exposure to cyclic heat stress by birds in different rearing phases, the literature is scarce in terms of periods of simulation of heat peaks occurring throughout the day (from $11 \mathrm{~h} 00$ to $14 \mathrm{~h} 00$ ) and their effects on the physiology of different commercial lines.

Exposing birds to cyclic heat stress potentially induces physiopathological alterations in their tissue development bone growth, mainly and gastrointestinal tract (PEARCE et al., 2013). Because it is a highly resistant and fast-growing bone, the tibia may be influenced by the environmental conditions to which the animals are exposed (VIEITES et al., 2016). Likewise, alterations may take place in intestinal structure and function (FARGHLY et al., 2018) and lymphoid organs may involute and reduce in size (OHTSU et al., 2015; BONFIM et al., 2016).

In Brazil, the farming of commercial broiler chicken lines has grown considerably. Therefore, further research should be carried out to investigate the effects of meteorological conditions on their production so that the activity can be increasingly efficient. On this basis, the present study proposes to examine bone parameters of the tibia, small intestine size (duodenum, jejunum and ileum) and weight of lymphoid organs (bursa of Fabricius and spleen) in Cobb and Hubbard broiler chickens exposed to heat for different daily periods from the 14 th to the 41 st day of life.

\section{Material and Methods}

All experimental procedures were previously approved by the Ethics Committee on Animal Use at the Federal University of Uberlândia (CEUA/ UFU; approval no: 065/14).

This study was undertaken from April to May 2015 in the poultry experimentation unit at the Federal University of Uberlândia (UFU), in Minas Gerais, Brazil. The shed was a conventional masonry/metal-structure type covered by asbestos tiles, lined with cemented floors, with screened walls and internal and external side curtains. 
Room temperature and air relative humidity were controlled by misters and fans. In the first week of the birds' life, infrared brooders were used to heat the chicks. Wood shavings were used as bedding material.

A total of 1120 male broiler chicks of the 560 Cobb Slow ${ }^{\circledR}$ and 560 Hubbard Flex ${ }^{\circledR}$ lines with an average weight of $44 \pm 2 \mathrm{~g}$ were acquired from a hatchery, originating from the same batch as breeder hens, and incubated under similar conditions, in the same machine. Chicks were housed in 32 cages measuring $1.90 \times 1.50 \mathrm{~m}$, in a randomized-block experimental design. Each cage was equipped with a trough-type feeder and an automatic chick drinker, which was later replaced by a pendulumtype drinker.

The birds were fed diets formulated with nutritional levels that would meet the requirements as recommended by Rostagno et al. (2011) (Table 1). The raw materials (sorghum, soybean meal and vegetable oil) were chemically analyzed to determine their nutritional composition. The feeding program was divided according to the bird's age: from one to seven days (pre-starter), eight to 21 days (starter), 22 to 33 days (grower) and 34 days until slaughter (finisher).

Table 1. Ingredients and centesimal composition of diets for broilers from 1-7 days (pre-starter), 8-21 days (starter), 22-33 days (grower) and 34-41 days (finisher).

\begin{tabular}{lcccc}
\hline Ingredient (\%) & Pre-starter & Starter & Grower & Finisher \\
\hline Ground sorghum 8.5\% CP & 52.87 & 56.94 & 58.51 & 63.35 \\
Soybean meal 46.0 & 40.69 & 36.68 & 34.04 & 29.07 \\
Vegetable oil & 2.71 & 2.85 & 4.17 & 4.61 \\
Calcitic limestone 36\% & 1.36 & 1.38 & 1.16 & 1.45 \\
Dicalcium phosphate 18.5 & 1.03 & 0.90 & 0.82 & 0.32 \\
Ground common salt & 0.50 & 0.45 & 0.38 & 0.36 \\
DL-methionine 98\% & 0.08 & 0.04 & 0.14 & 0.09 \\
L-threonine 98\% & 0.04 & 0.03 & 0.05 & 0.01 \\
Premix VMA FC & $0.70^{1}$ & $0.70^{1}$ & $0.70^{2}$ & $0.70^{3}$ \\
\hline TOTAL & 100 & 100 & 100 & 100 \\
\hline Nutritional levels & & & & \\
\hline Apparent metabolizable energy (Kcal kg-1) & 3.050 & 3.099 & 3.219 & 3.299 \\
Crude protein (\%) & 23.53 & 22.00 & 21.00 & 19.00 \\
Linoleic acid (\%) & 2.24 & 2.32 & 2.99 & 3.23 \\
Calcium (\%) & 1.03 & 1.00 & 0.90 & 0.90 \\
Available phosphorus (\%) & 0.48 & 0.45 & 0.43 & 0.33 \\
Potassium (\%) & 0.97 & 0.90 & 0.85 & 0.77 \\
Sodium (\%) & 0.23 & 0.21 & 0.18 & 0.17 \\
Digestible lysine (\%) & 1.28 & 1.18 & 1.16 & 1.00 \\
Digestible methionine (\%) & 0.65 & 0.59 & 0.59 & 0.49 \\
Digestible methionine+cystine (\%) & 0.96 & 0.88 & 0.87 & 0.75 \\
Digestible threonine (\%) & 0.81 & 0.75 & 0.74 & 0.64 \\
\hline Px starte (kg & & & \\
\hline
\end{tabular}

${ }^{1}$ Px starter $\left(\mathrm{kg} \mathrm{diet}^{-1}\right)$ : lysine $110 \mathrm{~g}$, methionine $350 \mathrm{~g}$, vit. A 1,000,000 IU, vit. D3 285,700 IU, vit. E 1,571 IU, vit. K3 $214 \mathrm{mg}$, vit. B1 $257 \mathrm{mg}$, vit. B2 $714 \mathrm{mg}$, vit. B6 $343 \mathrm{mg}$, vit. B12 1,428.50 mcg, niacin 5,000 mg, pantothenic acid 1,643 mg, folic acid 114.27 $\mathrm{mg}$, biotin $5.70 \mathrm{mg}$, choline $42.85 \mathrm{~g}$, manganese $8,570 \mathrm{mg}$, zinc $7,140 \mathrm{mg}$, iron $5,714 \mathrm{mg}$, copper 1,142.86 mg, iodine $114.30 \mathrm{mg}$, selenium $42.86 \mathrm{mg}$, phytase 71,429 un., protease 53,571 un., amylase 53,571 un., B-glucanase 44,643 un., xylanase 89,286 un., cellulase 80,357 un., ethoxyquin $9,524 \mathrm{mg}$, virginiamycin $2,358 \mathrm{mg}$, nicarbazin+maduramicin $6,250 \mathrm{mg}$. 
${ }^{2} \mathrm{Px}$ grower $\left(\mathrm{kg} \mathrm{diet}^{-1}\right)$ : lysine $170 \mathrm{~g}$, methionine $230 \mathrm{~g}$, vit. A 785,000 IU, vit. D3 171,000 IU, vit. E 1,428 IU, vit. K3 $171 \mathrm{mg}$, vit. B1 $171 \mathrm{mg}$, vit. B2 $571 \mathrm{mg}$, vit. B6 $271 \mathrm{mg}$, vit. B12 1,142 mcg, niacin 4,000 mg, pantothenic acid 1,285 mg, folic acid 85.70 $\mathrm{mg}$, choline $37.19 \mathrm{~g}$, manganese $8,500 \mathrm{mg}$, zinc 7,100 mg, iron 5,700 mg, copper 1,142 mg, iodine $114 \mathrm{mg}$, selenium $35.70 \mathrm{mg}$, ethoxyquin 9,430 mg, phytase 71,429 un., protease 53,571 un., amylase 53,571 un., B-glucanase 44,643 un., xylanase 89,286 un., cellulase 80,357 un., virginiamycin $2,357 \mathrm{mg}$, salinomycin 9,428.57 mg.

${ }^{3}$ Px finisher $\left(\mathrm{kg} \mathrm{diet}^{-1}\right)$ : lysine $114 \mathrm{~g}$, methionine $187 \mathrm{~g}$, vit. A 285,714 IU, vit. D3 71,429 IU, vit. E $785.71 \mathrm{IU}$, vit. K3 78.56 mg, vit. B2 $285.70 \mathrm{mg}$, vit. B12 $714.28 \mathrm{mcg}$, niacin 2,857 mg, pantothenic $928.60 \mathrm{mg}$, choline $17.10 \mathrm{~g}$, manganese 8,570 mg, zinc 7,143 $\mathrm{mg}$, iron 5,714 mg, copper 1,142.86 mg, iodine $114.30 \mathrm{mg}$, selenium $28.57 \mathrm{mg}$, phytase 71,430 un., protease 53,571 un., amylase 53,571 un., B-glucanase 44,643 un., xylanase 89,286 un., cellulase 80,357 un., ethoxyquin 9,524 mg.

During the experimental period, feed and chlorinated water (3-5 $\mathrm{mg} \mathrm{mL}^{-1}$ chlorine) were available to the animals ad libitum. The lighting program consisted of two (1-7 days), four (8-21 days) and two (22-41) hours of darkness per day.

The birds were maintained under thermal conditions as recommended for the lines from the first to the 13th day of age. From the 14th to the 41st day, during exposure to elevated temperatures, the shed was divided into four sections, each measuring $5.60 \mathrm{~m}$ (width) $\times 10.20 \mathrm{~m}$ (length) $\times 2.80 \mathrm{~m}$ (height), separated by double-sided plastic curtains (black and white) arranged transversely to the shed with the white side exposed. In this way, four thermal environments were set up, each containing eight cages, four per line. In the control environment (E0), the birds remained under thermal conditions as recommended for the line until slaughter. In the other environments (E1, E2 and E3), the birds were exposed to high temperatures for 1, 2 or $3 \mathrm{~h}$ per day, respectively, which started at $11 \mathrm{~h} 00$.

Thermal comfort was ensured by using fans and misters, which were activated according to the temperature recorded in the shed. The temperature and air humidity were monitored at every ten minutes by three data loggers (HOMIS 404A), which were installed at $30 \mathrm{~cm}$ above the poultry litter (Table 2).

Table 2. Mean values and standard deviation for temperature $\left({ }^{\circ} \mathrm{C}\right)$ and air relative humidity $(\%)$ in the shed where broilers were exposed to heat for different periods.

\begin{tabular}{ccccc}
\hline & \multicolumn{2}{c}{ Temperature $\left({ }^{\circ} \mathrm{C}\right)^{*}$} & \multicolumn{2}{c}{ Humidity $(\%) *$} \\
\hline Age (days) & Control & Stress & Control & Stress \\
\hline $14-20$ & $26.6 \pm 1.9$ & $35.1 \pm 1.1$ & $63.9 \pm 5.5$ & $65.2 \pm 2.2$ \\
$21-27$ & $25.9 \pm 1.7$ & $34.2 \pm 0.9$ & $63.4 \pm 2.1$ & $55.2 \pm 1.5$ \\
$28-34$ & $24.8 .2 \pm 2.2$ & $33.2 \pm 0.9$ & $67.9 \pm 6.3$ & $58.7 \pm 1.1$ \\
$35-41$ & $27.0 \pm 1.6$ & $32.3 \pm 0.8$ & $60.0 \pm 2.8$ & $60.3 \pm 2.0$ \\
\hline
\end{tabular}

* Measurements performed daily from $11 \mathrm{~h} 00$ to $14 \mathrm{~h} 00$, at every $10 \mathrm{~min}$, in the four thermal environments (control: following the recommendations for the line; cyclic heat stress for up to three hours).

Cyclic heat stress was generated by infrared brooders at the following mean temperatures: $14-21$ days: $36{ }^{\circ} \mathrm{C}$; $21-27$ days: $35{ }^{\circ} \mathrm{C}$; $28-34$ days: $34{ }^{\circ} \mathrm{C}$; and $35-42$ days: $33^{\circ} \mathrm{C}$. Fans were activated along with artificial heating. The $\mathrm{CO}_{2}$ concentration was measured daily by reading the Li-cor ${ }^{\circledR}$ LI- 8100 instrument, which was installed at the height of the birds.
At 42 days of age, all birds were weighed and 48 animals whose weight was within the average range of each cage were selected (six from each treatment) to be slaughtered. The birds were feed-deprived 12 $\mathrm{h}$ before slaughter, following official norms and procedures. Next, necropsy was performed and the intestinal portions (duodenum, jejunum and ileum) were measured using a tape measure graduated in 
centimeters. The absolute weights of spleen and bursa of Fabricius were determined using a 0.01-g precision scale (9094, Toledo), and the weights of those organs relative to the birds' live weight were subsequently calculated.

The right tibiae were cleaned off of adherent tissues and pre-dried in a forced-air oven in the laboratory at $56{ }^{\circ} \mathrm{C}$ for $72 \mathrm{~h}$. Subsequently, the length and width (in the middle region) were measured using a digital caliper. Tibia bone density was determined using a $100-\mathrm{mL}$ graduated beaker with approximately $80 \mathrm{~mL}$ of absolute alcohol, by applying the following formula: $\mathrm{BD}=\mathrm{TW} /(\mathrm{FV}-\mathrm{IV})$, where BD: bone density $\left(\mathrm{g} \mathrm{mL}^{-1}\right)$; $\mathrm{TW}$ : tibia weight (g); IV: the 80-mL absolute alcohol volume; and FV: the final volume found by the reading $(\mathrm{mL})$ obtained with the displacement of the alcohol volume in the beaker after the bone was placed in it. The tibiae were then dried, weighed and placed in a muffle at $600{ }^{\circ} \mathrm{C}$ for $4 \mathrm{~h}$ to determine mineral matter (\%MM).

The collected data were evaluated for normality by the Shapiro Wilk test and for homogeneity by the Levene test and subsequently subjected to analysis of variance using SISVAR ${ }^{\circledR}$ software, where the means were contrasted by the Scott-Knott test at the $5 \%$ probability level.

\section{Results and Discussion}

The temperatures reached in the heated environment were always above the that in the "control" environment, as established for each bird rearing week, whereas the air relative humidity values were maintained at the standard values recommend for the lines, both in the control and heat-stressed environments (Table 2), as were the $\mathrm{CO}_{2}$ contents.

Heat stress and the lines did not influence small intestine morphometry (Table 3). In the present study, heat stress was cyclic (one to three daily hours under high temperatures and 23 to $21 \mathrm{~h}$ under ideal temperatures); thus, the finding that small intestine morphometry was not changed by heat can be partly explained by the compensation occurring at nighttime and in the other moments when the birds were under ideal temperatures (BALNAVE, 2004; BUENO et al., 2017). As regards the line, a possible explanation for the lack of effects is that body weight did not differ between the two (Table 4). In this way, the allometric development of the small intestine accompanied body weight.

Table 3. Mean values of the small intestine (SI) and its portions (duodenum - D, jejunum - J and ileum - I) in commercial broilers of two lines exposed to heat for different periods.

\begin{tabular}{lcccccccc}
\hline & \multicolumn{3}{c}{ Thermal environment } & \multicolumn{5}{c}{ Line } \\
\hline & E0 & E1 & E2 & E3 & P-value & Cobb & Hubbard & P-value \\
\hline $\mathrm{D}(\mathrm{cm})$ & 27.92 & 27.58 & 28.00 & 29.25 & 0.3101 & 27.92 & 28.46 & 0.4153 \\
$\mathrm{~J}(\mathrm{~cm})$ & 65.08 & 60.83 & 61.58 & 64.92 & 0.2216 & 62.00 & 64.21 & 0.2240 \\
$\mathrm{I}(\mathrm{cm})$ & 68.00 & 65.42 & 68.25 & 65.83 & 0.7599 & 65.54 & 68.21 & 0.2591 \\
$\mathrm{SI}(\mathrm{cm})$ & 161.00 & 153.83 & 157.83 & 160.00 & 0.4897 & 155.46 & 160.88 & 0.1301 \\
\hline
\end{tabular}

Means followed by different letters in the same row, within each parameter: Environment and Lines differ significantly from each other $(\mathrm{p}<0.05)$ according to the Scott-Knott test. E0: control - following the recommendations for the line and environment with exposure to heat for $1 \mathrm{~h} /$ day (E1); $2 \mathrm{~h}$ /day (E2) and $3 \mathrm{~h} /$ day (E3). 
Table 4. Mean values for live weight (LW), absolute weight (AW) and relative weight (RW) of bursa and spleen, in grams, of commercial broilers of two lines exposed to heat for different periods.

\begin{tabular}{lcccccccc}
\hline & \multicolumn{3}{c}{ Thermal environment } & \multicolumn{5}{c}{ Line } \\
\hline & E0 & E1 & E2 & E3 & P-value & Cobb & Hubbard & P-value \\
$\mathrm{LW}(\mathrm{kg})$ & 2.90 & 2.83 & 2.91 & 2.95 & 0.0706 & 2.91 & 2.89 & 0.4226 \\
$\mathrm{AW}_{\text {BURSA }}(\mathrm{g})$ & 5.45 & 5.47 & 6.60 & 6.62 & 0.1313 & $5.37 \mathrm{a}$ & $6.70 \mathrm{~b}$ & 0.0073 \\
$\mathrm{RW}_{\text {BURSA }}(\%)$ & 0.19 & 0.19 & 0.23 & 0.23 & 0.2118 & $0.18 \mathrm{a}$ & $0.23 \mathrm{~b}$ & 0.0057 \\
$\mathrm{AW}_{\text {SPLEEN }}(\mathrm{g})$ & 2.62 & 2.65 & 2.89 & 2.65 & 0.7006 & 2.67 & 2.73 & 0.7217 \\
$\mathrm{RW}_{\text {SPLEEN }}(\%)$ & 0.09 & 0.09 & 0.10 & 0.09 & 0.7431 & 0.09 & 0.09 & 0.8365 \\
\hline
\end{tabular}

Means followed by different letters in the same row, within each parameter: Thermal environment and Lines differ significantly from each other $(\mathrm{p}<0.05)$ according to the Scott-Knott test. E0: natural temperature conditions and environment with exposure to heat for $1 \mathrm{~h}$ /day (E1); $2 \mathrm{~h}$ /day (E2) and $3 \mathrm{~h}$ /day (E3).

According to $\mathrm{He}$ et al. (2018), the growth of an animal depends on the degree of development of its digestive organs. Those authors subjected broiler chickens to chronic stress; i.e., $32{ }^{\circ} \mathrm{C}$ for 24 h daily, from 28 to 42 days of age, and ad libitum feeding. Two groups were reared under comfort ( 22 ${ }^{\circ} \mathrm{C}$ ) — one fed ad libitum and another feed-restricted (receiving the amount consumed by the birds in the stressed group on the previous day). The intestinal length of the birds reared under heat and fed ad libitum increased, compared to those reared under thermal comfort with and without feed restriction. The researchers attributed this result to the lower body weight gain of the animals under stress, since they showed the highest relative intestinal length among the groups. The authors went on to state that there may be a compensation mechanism to cope with the loss caused by heat stress. However, no such alterations were observed in the present study.

The relative and absolute weights of spleen were not influenced by the lines. However, the Hubbard birds showed higher absolute and relative weights of the bursa of Fabricius compared to the Cobb chickens (Table 4). The thermal environment did not influence the relative or absolute weights of the bursa or spleen at 42 days of age (Table 4).

The Hubbard chickens showed a higher relative weight of the bursa. This finding corroborates those reported by Makram et al. (2010), who found that the relative and absolute weights of the lymphoid organs (spleen and bursa) in the Hubbard line were higher when compared to two other commercial lines (Cobb and Avian).

The thermal environments to which the birds were subjected did not influence the weight of their lymphoid organs. This is in contrast to results reported by some authors such as Engan and Schagatay (2015), who declared that any stressful factor leads to hemodynamic alterations, causing a reduction in the size and relative weight of the spleen. Many studies in birds report chronic heat stress as an immunosuppressant factor, which shows that the bird's cloacal bursa is subject to environmental alterations (DHABHAR, 2014) that can induce an immune response in the animal (HONDA et al., 2015).

Upon being subjected to stress, birds respond with an increase in corticosterone synthesis (OHTSU et al., 2015; GONZÁLEZ; SILVA, 2017), which leads to alterations in the relative weights of spleen and bursa of Fabricius (CALEFI et al., 2016) that may affect their immunity. Although the corticosterone levels were not evaluated in the current study, it is known that birds under cyclic heat stress maintain their basal glucocorticoid levels without detriment to the lymphoid organs, since they can offset their losses in the fresher periods of the day. 
No interaction effect between environment and line was detected on the bone parameters; thus, both were evaluated separately. Birds reared in the environment with high temperatures for two to three hours daily showed a longer and narrower tibia from the 14th day of life (Table 5), although density and mineral matter did not differ between the thermal environments.

Table 5. Mean values of total length (TL), width (W), density (D) and mineral matter (MM) in the tibia of commercial broilers of two lines exposed to heat for different periods.

\begin{tabular}{lcccccccc}
\hline & \multicolumn{3}{c}{ Thermal environment } & \multicolumn{3}{c}{ Line } \\
\hline & E0 & E1 & E2 & E3 & P-value & Cobb & Hubbard & P-value \\
$\mathrm{TL}(\mathrm{mm})$ & $104.83 \mathrm{a}$ & $106.12 \mathrm{a}$ & $109.42 \mathrm{~b}$ & $108.72 \mathrm{~b}$ & 0.0025 & $105.90 \mathrm{a}$ & $108.64 \mathrm{~b}$ & 0.0044 \\
$\mathrm{~W}(\mathrm{~mm})$ & $10.31 \mathrm{~b}$ & $10.27 \mathrm{~b}$ & $9.74 \mathrm{a}$ & $9.70 \mathrm{a}$ & 0.0089 & $9.58 \mathrm{a}$ & $10.44 \mathrm{~b}$ & 0.0000 \\
$\mathrm{D}\left(\mathrm{g} \mathrm{mL}^{-1}\right)$ & 1.26 & 1.24 & 1.40 & 1.25 & 0.2970 & 1.29 & 1.29 & 0.9406 \\
$\mathrm{MM}(\%)$ & 43.76 & 46.19 & 46.15 & 46.36 & 0.2425 & 45.40 & 45.86 & 0.6363 \\
\hline
\end{tabular}

Means followed by different letters in the same row, within each parameter: Environment and Lines differ significantly from each other $(\mathrm{p}<0.05)$ according to the Scott-Knott test. E0: control - following the recommendations for the line and environment with exposure to heat for $1 \mathrm{~h}$ /day (E1); $2 \mathrm{~h}$ /day (E2) and $3 \mathrm{~h}$ /day (E3).

One hypothesis would be that bone tissue is influenced by endogenous and exogenous factors (e.g. temperature, housing density, moving around in the shed) during all rearing stages, which would lead to structural differences that culminate in bone deformities and distortions (OLIVEIRA et al., 2014; MARCHINI et al., 2018). However, Marchini et al. (2018) mentioned that birds exposed to one hour of heat daily do not have their tibia morphology altered, and these alterations are possibly more noticeable in longer periods and/or periods of more intense heat stress.

A presumed interpretation for the lack of differences in density and mineral matter of the tibia between the thermal environments is the fact that mineral deposition in the bird skeleton is more intense in the initial weeks; i.e., until 21 days of age (OLIVEIRA et al., 2014); thus, the seven days of exposure to high temperatures (14 to 21 days of age) were not sufficient to cause alterations in mineral matter and density, in relation to the 14 days the birds remained under comfort. Moreover, the intensity and duration of heat stress were not sufficient to affect mineral deposition in the tibia, since the birds managed to recover from the stress they had undergone during the fresher times of the day (BALNAVE, 2004; BUENO et al., 2017).

The Hubbard line showed longer and wider tibia than the Cobb chickens (Table 5); however, bone density and mineral matter did not differ between the lines. A possible explanation for the longer and wider tibia is the larger bone structure of the Hubbard line. These data corroborate Flemming et al. (1999), who found differences between the relative weight of the leg bone between two commercial lines (Cobb, 21.54\% $\times$ Hubbard, 23.51\% relative weight compared to the total leg weight) and Silva et al. (2017), who found a higher leg yield in the Hubbard line $(26.52 \%)$ compare to Cobb (25.14\%).

Oliveira et al. (2014) stated that, overall, there are no bone differences between rapidgrowing commercial broiler lines and that delayed development of long bones (e.g., tibia, femur and humerus) occurs in free-range birds.

\section{Conclusions}

Cyclic heat stress for two to three hours daily increases the length and reduces the width of the 
tibia in broiler chickens, but does not influence the morphometry of their small intestine or lymphoid organs. The Hubbard line has a better tibia development and heavier bursa of Fabricius than the Cobb line.

\section{Acknowledgments}

The authors thank Fapemig (Foundation for Research Support of the State of Minas Gerais) for financing the research (Universal APQ- 01292-13).

\section{References}

ALAGAWANY, M.; FARAG, M. R.; ABD EL-HACK, M. E.; PATRA, A. Heat stress: effects on productive and reproductive performance of quail. World's Poultry Science Journal, Cambridge, v. 73, n. 4, p. 747-756, 2017. DOI: $10.1017 /$ S0043933917000782

BALNAVE, D. Challenges of accurately defining the nutrient requirements of heat-stressed poultry. Poultry Science, College Station, v. 83, n. 1, p. 5-14, 2004. DOI: $10.1093 / \mathrm{ps} / 83.1 .5$

BONFIM, D. S.; SIQUEIRA, J. C.; BOMFIM, M. A. D.; RIBEIRO, F. B.; OLIVEIRA, F. L.; NASCIMENTO, D. C. N.; MELO, S. A. Productive characteristics of meat quails reared in different environments. Semina: Ciências Agrárias, Londrina, v. 37, n. 6, p. 4313-4326, 2016. DOI: 10.5433/1679-0359.2016v37n6p4313

BUENO, J. P. R.; NASCIMENTO, M. R. B. M.; MARTINS, J. M. S.; MARCHINI, C. F. P.; GOTARDO, L. R. M.; SOUSA, G. M. R.; MUNDIM, A. V.; GUIMARÃES, E. C.; RINALDI, F. P. Effect of age and cyclical heat stress on the serum biochemical profile of broiler chickens. Semina: Ciências Agrárias, Londrina, v. 38, n. 3, p. 1383-1392, 2017. DOI: $10.5433 / 1679-0359.2017 \mathrm{v} 38 \mathrm{n} 3 \mathrm{p} 1383$

CALEFI, A. S.; SIQUEIRA, A.; NAMAZU, L. B.; COSTOLA-DE-SOUZA, C.; HONDA, B. B.; FERREIRA, A. J.; QUINTEIRO-FILHO, W. M.; SILVA FONSECA, J. G.; PALERMO-NETO, J. Effects of heat stress on the formation of splenic germinal centres and immunoglobulins in broilers infected by Clostridium perfringens type A. Veterinary Immunology and Immunopathology, Amsterdam, v. 171, p. 38- 46, 2016. DOI: $10.1016 /$ j.vetimm.2016.02.004

DHABHAR, F. S. Effects of stress on immune function: the good, the bad, and the beautiful. Immunologic
Research, Basel, v. 58, n. 2-3, p. 193-210, 2014. DOI: 10.1007/s12026-014-8517-0

ENGAN, H.; SCHAGATAY, E. Spleen contraction and hemoconcentration regarding the review Hemoconcentration and hemostasis during acute stress: interacting and independent effects by Austin et al. 2011. Annals of Behavioral Medicine: a publication of the Society of Behavioral Medicine, Rockville MD, v. 49, n. 4, p. 634-635, 2015. DOI: /10.1007/s12160-015-9707-2

FARGHLY, M. F. A.; ABD EL-HACK, M. E.; ALAGAWANY, M.; SAADELDIN, I. M.; SWELUM, A. A. Wet feed and cold water as heat stress modulators in growing Muscovy ducklings. Poultry Science, College Station, v. 97 , n. 5, p. $1588-1594$, 2018. DOI: $10.3382 /$ ps/pey006

FLEMMING, J. S.; JANZEN, S. A.; ENDO, M. A. Rendimento de carcaças em linhagens comerciais de frangos de corte. Archives of Veterinary Science, Curitiba, v. 4, n. 1, p. 61-63, 1999. DOI: 10.5380/avs. v4i1.3781

GONZÁLEZ, F. H. D.; SILVA, S. C. Introdução à bioquímica clínica veterinária. Porto Alegre: UFRGS, 2017. 535 p.

HE, X.; LU, Z.; MA, B.; ZHANG, L.; LI, J.; JIANG, Y.; ZHOU, G.; GAO, F. Chronic heat stress damages small intestinal epithelium cells associated with the adenosine 5 '-monophosphate-activated protein kinase pathway in broilers. Journal of Agricultural and Food Chemistry, Washington, v. 66, n. 28, p. 7301-7309, 2018. DOI: 10.1021/acs.jafc.8b02145

HONDA, B. T.; CALEFI, A. S.; COSTOLA-DE-SOUZA, C.; QUINTEIRO-FILHO, W. M.; SILVA FONSECA, J. G.; PAULA, V. F.; PALERMO-NETO, J. Effects of heat stress on peripheral $\mathrm{T}$ and $\mathrm{B}$ lymphocyte profiles and IgG and IgM serum levels in broiler chickens vaccinated for Newcastle disease virus. Poultry Science, College Station, v. 94 , n. 10, p. 2375-2381, 2015. DOI: $10.3382 /$ ps/pev192

MAKRAM, A.; GALAL, A.; FATHI, M. M.; EL-ATTAR, A. H. Carcass characteristics and immunocompetence parameters of four commercial broiler strain chickens under summer season of Egypt. International Journal of Poultry Science, Faisalabad, v. 9, n. 2, p. 171-176, 2010. DOI: 10.3923/ijps.2010.171.176

MARCHINI, C. F. P.; CAFÉ, M. B.; NASCIMENTO, M. R. B. M.; FERNANDES, E. A.; BELETTI, M. E.; GUIMARÃES, E. C. Tibia bone integrity in broilers subjected to cyclic heat stress. Ciência Animal Brasileira, Goiânia, v. 19, p. 1-10, 2018. DOI: 10.1590/18096891v19e-38035 
OHTSU, H.; YAMAZAKI, M.; ABE, H.; MURAKAMI, H.; TOYOMIZU, M. Heat stress modulates cytokine gene expression in the spleen of broiler chickens. The Journal of Poultry Science, Tsukuba, v. 52, n. 4, p. 282287, 2015. DOI: 10.2141/jpsa.0150062

OLIVEIRA, A. F. G.; BRUNO, L. D. G.; MARTINS, E. N.; GARCIA, E. R. M.; MONTEIRO, A. C.; LEITE, M. C. P.; POZZA, P. C.; SANGALI, C. P. Effect of stocking density and genetic group on mineral composition and development of long bones of broilers. Semina: Ciências Agrárias, Londrina, v. 35, n. 2, p. 1023-1034, 2014. DOI: 10.5433/1679-0359.2014v35n2p1023

PEARCE, S. C.; MANI, V.; BODDICKER, R. L.; JOHNSON, J. S.; WEBER, T. E.; ROSS, J. W.; RHOADS, R. P.; BAUMGARD, L. H.; GABLER, N. K. Heat stress reduces intestinal barrier integrity and favors intestinal glucose transport in growing pigs. Plos One, San Francisco, v. 8, n. 8, p. 1-9, 2013. DOI: 10.1371/ journal.pone.0070215

ROSTAGNO, H. S.; ALBINO, L. F. T.; DONZELE, J. L.; GOMES, P. C.; OLIVEIRA, R. F.; LOPES, D. C.; FERREIRA, A. S.; BARRETO, S. L. T.; EUCLIDES, R. F. Tabelas brasileiras para aves e suínos: composição de alimentos e exigências nutricionais de aves e suínos. 3 . ed. Viçosa: UFV, 2011. 252 p.

SILVA, M. T. P.; VELOSO, R. C.; PIRES, A. V.; TORRES FILHO, R. A.; PINHEIRO, S. R. F.; WINKELSTROTER, L. K.; BARROS, F. J. M.; SENNA, J. A. B. Desempenho e características de carcaça de três genótipos comerciais de frangos de corte alimentados com diferentes dietas. Arquivo Brasileiro de Medicina Veterinária e Zootecnia, Belo Horizonte, v. 69, n. 5, p. 1311-1318, 2017. DOI: 10.1590/1678-4162-8241

UZUM, M. H.; ORAL TOPLU, H. D. Effects of stocking density and feed restriction on performance, carcass, meat quality characteristics and some stress parameters in broilers under heat stress. Revue de Médecine Vétérinaire, Paris, v. 164, n. 12, p. 546-554, 2013.

VIEITES, F. M.; DROSGHIC, L. C. A. B.; SOUZA, C. S.; VARGAS JUNIOR, J. G.; NUNES, R. V.; MORAES, G. H. K.; CORREA, G. S. S.; CARAMORI JUNIOR, J. G. Bone characteristics of broiler chickens fed diets supplemented with Solanum glaucophyllum. Semina: Ciências Agrárias, Londrina, v. 37, n. 1, p. 381-392, 2016. DOI: $10.5433 / 1679-0359.2016 v 37 n 1 p 381$ 
